\title{
Behavioral responses of Trachemys dorbigni (Duméril \& Bibron, 1835) (Testudines: Emydidae) facing a potential risk of predation
}

\section{Thiago Maia-Carneiro*, Thiago Arnt Dorigo and Carlos Frederico Duarte Rocha}

Departamento de Ecologia. Universidade do Estado do Rio de Janeiro. Rua São Francisco Xavier, 524. Rio de Janeiro. Brazil. (CEP 20550-013). *Email: tmaiacarneiro@gmail.com.

\begin{abstract}
Behavioral responses in front of potential predation risks are critical for survival and diverse among reptiles. Trachemys dorbigni (Duméril \& Bibron, 1835) (Testudines: Emydidae) is a terrapin species of the Family Emydidae with geographical distribution along Southern South America. Here, we report behavioral responses displayed by a $T$. dorbigni individual facing potential risk of predation. After captured, the individual withdrawn head and limbs into the carapace and, shortly after released, it ran toward a deeper region of a pond and dig the muddy substrate through movements of its carapace and paws burying itself into the mud submerged in water. Withdrawal into the carapace, flight into water or a burrow, and similar burial behaviors occur in Testudines, but until now they were not reported in $T$. dorbigni. These animals might use the behavioral responses reported here when facing risks of predation, which may difficult capturing and therefore increase chances of survival.
\end{abstract}

Keywords: Defensive mechanisms; Predation; Terrapin; Testudines; Turtle.

Behavioral responses in front of potential predation risks are critical for survival and are greatly diverse among reptiles (Greene, 1988). Trachemys dorbigni (Duméril \& Bibron, 1835) is a terrapin species of the Family Emydidae with geographical distribution encompassing Uruguay, Argentina and
Received

October 29, 2016

Accepted

December 3, 2016

Released

December 31, 2016

Open Acess

Full Text Article

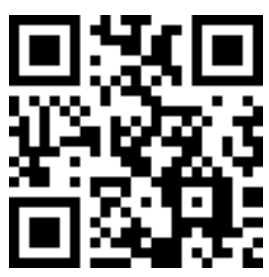

ORCID

(1) 0000-0002-9217-8783

Thiago Maia-Carneiro

(D) 0000-0002-8742-2366

Thiago Arnt Dorigo

(D) 0000-0003-3000-1242

Carlos Frederico Duarte

Rocha
Brazil that occur in wetlands and in lentic and lotic freshwater environments (Bujes and Verrastro, 2008; Bujes, 2010). Previous studies approached different aspects of the natural history of this species, such as reproduction and the use of spatial and trophic resources (see Bujes, 2010 for a review). Here, we report behavioral 
responses displayed by a $T$. dorbigni individual facing a potential risk of predation.

On 15 July 2008, in the Parque Estadual da Serra do Tabuleiro, Restinga (sand dune plains) of the Baixada do Maciambu, Municipality of Palhoça, State of Santa Catarina, Brazil $\left(27^{\circ} 49^{\prime} 34^{\prime \prime}\right.$ -

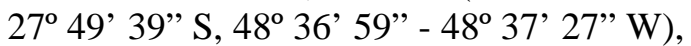
around $15: 15 \mathrm{~h}$, we sighted a T. dorbigni individual swimming in a pond. We captured the terrapin manually and when we handled the individual, it responded with withdrawn of head and limbs into the carapace (Figure 1A). We released the individual at the margin of the pond where it was caught and, shortly after released, the individual started running toward a deeper region of the pond (Figure 1B) and dig the muddy substrate through movements of its carapace and paws (Figure 1C). The sequence of movements after we released the individual lasted approximately $30 \mathrm{~s}$ and, finally, the terrapin buried itself into the mud submerged in water (Figure 1D).

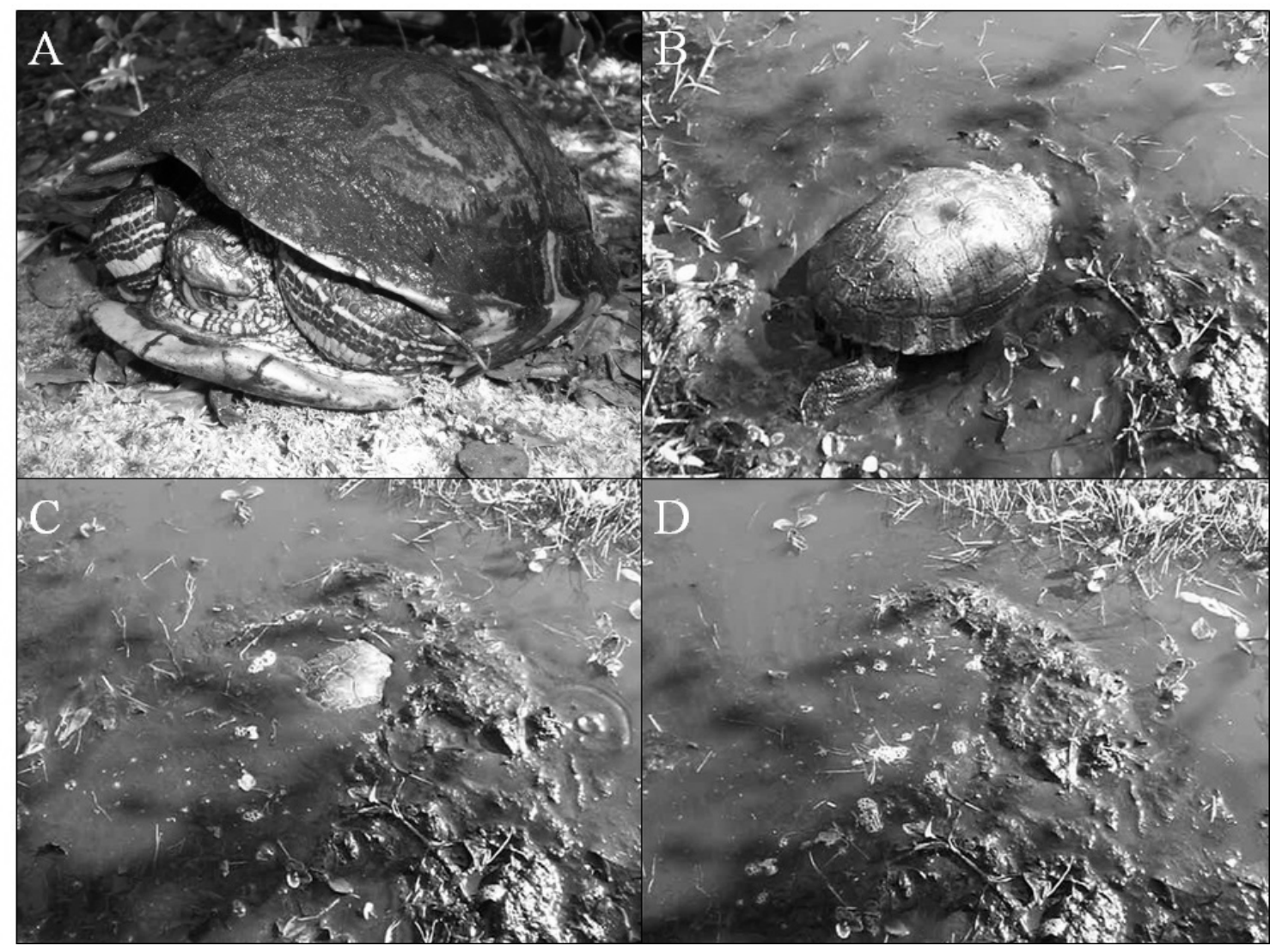

Figure 1. Defensive behaviors exhibited by Trachemys dorbigni in the Municipality of Palhoça, State of Santa Catarina, Brazil. When the individual was caught (A) it withdrawn head and limbs into the carapace. Shortly after released, (B) the terrapin started running toward a deeper region of the pond (note the right hind paw extended) and (C) dig the muddy substrate through movements of its carapace and paws. Approximately $30 \mathrm{~s}$ after we released the individual, (D) it completely buried itself in mud submerged in water. Note in $\mathrm{C}$ and $\mathrm{D}$ the mud that emerged from the bottom of the pond due to movements of the terrapin, which is not present in B at the beginning of the individual's locomotor escape. Photographs by Thiago Maia-Carneiro. 
Withdrawal into the carapace and flight into water or a burrow is common in testudines (turtles, terrapins, and tortoises Greene, 1988). Considering the burial, similar behaviors are reported to occur for example in Terrapene carolina bauri (Linneus, 1758) (Emydidae) (Jennings, 2007) and in Phrynops tuberosus (Peters, 1870) (Chelidae) (Rodrigues and Silva, 2013), but until now these behaviors were not reported in T. dorbigni. We made unsuccessful inspections to find the T. dorbigni individual sometime after it buried itself, suggesting that it moved under the mud, supposedly for avoidance of the potential risk of predation, which could be a fourth behavioral response. However, as the pond where we captured the terrapin was large and its water muddy and dark, we could not state whether the individual actually slipped into the mud because it was in a shallow part and went out elsewhere in a deeper region of the pond or whether it buried itself in the mud and gone out shortly after the burying. It is worth noting that stressing conditions during manipulation might have influenced the behavioral responses by the $T$. dorbigni individual in Baixada do Maciambu, however, they were analogous to those that may be experienced in real predation attempts.

Both invertebrates (insects - Parris et al., 2002) and vertebrates (fishes, frogs, lizards, snakes, birds, crocodilians, alligators, and humans - Greene, 1988; Gyuris, 1994; Janzen et al., 2000; Bujes, 2010, and references therein, Maia et al., 2012) might be threats for Testudines. These animals might use the behavioral responses reported here (withdrawal of head and limbs into the carapace, locomotor escape, and burial) when facing risks of predation, which may difficult capturing and therefore increase chances of survival.

\section{Acknowledgements}

This study was supported by research grants from the Conselho Nacional de Desenvolvimento Científico e Tecnológico (CNPq) (Processes no.
304791/2010-5 and no. 470265/2010-8) and from the Fundação Carlos Chaga Filho de Amparo à Pesquisa do Estado do Rio de Janeiro (FAPERJ) through the program "Cientistas do Nosso Estado" (Process E-26/102.404.2009) to C. F. D. Rocha. T. Maia-Carneiro received a M. Sc. grant from Coordenação de Aperfeiçoamento de Pessoal de Nível Superior (Capes).

\section{Conflicts of interest}

Authors declare that they have no conflict of interests.

\section{References}

Bujes, C. S.; Verrastro, L. Quelônios do delta do Rio Jacuí, RS, Brasil: uso de hábitats e conservação. Natureza \& Conservação, v. 6, no. 2, p. 47-60, 2008.

Bujes, C. S. Os Testudines continentais do Rio Grande do Sul, Brasil: taxonomia, história natural e conservação. Iheringia Série Zoologia, v. 100, n. 4, p. 413-424, 2010. http://dx.doi.org/10.1590/S007347212010000400016

Greene, H. W. Anti-predator mechanisms in reptiles. In Gans, C.; Huey, R. B. (Eds.). Biology of the Reptilia, 16. New York: Allan R. Liss, 1988. p. 1-152.

Gyuris, E. The rate of predation by fishes on hatchlings of the green turtle (Chelonia mydas). Coral Reefs, v. 13, p. 137-144, 1994.

Janzen, F. J.; Tucker, J. K.; Paukstis, G. L. Experimental analysis of an early life-history stage: avian predation selects for larger body size of hatchling turtles. Journal of Evolutionary Biology, v. 13, p. 947-954, 2000. http://dx.doi.org/10.1046/j.1420-9101.2000. 00234.x

Jennings, A. H. Use of habitats and microenvironments by juvenile florida box turtles, Terrapene carolina bauri, on Egmont Key. Herpetologica, v. 63, no. 1, p. 1-10, 2007. http://dx.doi.org/10.1655/0018-0831(2007) 63[1:UOHAMB]2.0.CO;2

Maia, A. C. R.; Rosa, C. A.; Bager, A. Predation of adult freshwater turtles in a protected area in Southernmost Brazil. Herpetological Bulletin, v. 120, p. 29-31, 2012. Available from: <http://thebhs.org/ index.php?option $=$ com_docman\&task $=$ doc_do wnload\&gid=92\&Itemid=35>. Accessed on: Apr. 24, 2016. 
Parris, L. B.; Lamont, M. M.; Carthy, R. R. Increased incidence of red imported fire ant (Hymenoptera: Formicidae) presence in loggerhead sea turtle (Testudines: Cheloniidae) nests and observations of hatchling mortality. Florida Entomologist, v. 85, no. 3, p. 514-517, 2002.

Rodrigues, J. F. M.; Silva, J. R. F. Phrynops tuberosus (ncn): defensive behaviour. Herpetological Bulletin, v. 124, p. 28, 2013. Available from: <http://www.thebhs.org/ index.php?option=com_docman\&task=doc_do wnload\&gid=254\&Itemid=35>. Accessed on: Apr. 24, 2016.

License information: This is an open-access article distributed under the terms of the Creative Commons Attribution License, which permits unrestricted use, distribution, and reproduction in any medium, provided the original work is properly cited. 